\title{
Preparation and Microstructure of Ir-Zr-W Alloys by Pow- der Metallurgy Route
}

\author{
Xiang Changshu, \\ Ge Yuan, \\ Liu Haiyan, \\ Huang Yuanping, \\ Tang Huiping
}

State Key Laboratory of Porous Metal Materials, Northwest Institute for Nonferrous Metal Research, Xi'an 710016, China

\begin{abstract}
Iridium alloys doped with approximate $4 \mathrm{at} \% \mathrm{Zr}$ and 0.3 at $\% \mathrm{~W}$ alloying elements were fabricated for ultra-high temperature applications by powder metallurgy route. The phase compositions and microstructures of the composite powders and the alloy were investigated. It was found that $\mathrm{Ir}_{3} \mathrm{Zr}$ phase could not form and no mechanical alloying phenomenon occurred when the composite powder of Ir- $\mathrm{ZrH}_{2}-\mathrm{W}$ was prepared by high-energy ball milling even for $24 \mathrm{~h}$, but it could be completely transmitted to $\operatorname{Ir}_{3} \mathrm{Zr}$ phase after calcinating at $1300{ }^{\circ} \mathrm{C}$. The average grain size of the alloy prepared by the powder metallurgy route was $4-5 \mu \mathrm{m}$, and $\mathrm{Ir}_{3} \mathrm{Zr}$ phase was generated in-situ in Ir-based alloy during sintering process.
\end{abstract}

Key words: iridium; microstructure; sintering; powder metallurgy

Iridium has been widely used for making crucibles, thermocouples, rocket parts, gas-turbine blades, equipments for glass making and spark plugs etc. because of its attractive properties, such as high melting point $\left(2443{ }^{\circ} \mathrm{C}\right)$, good oxidation resistance and high strength at elevated temperature ${ }^{[1,2]}$.

Though iridium is a face centered cubic metal, it fractures in a brittle manner similar to that of body centered cubic metal at temperature below $1000{ }^{\circ} \mathrm{C}^{[3]}$. Some alloying elements such as $\mathrm{W}, \mathrm{Nb}, \mathrm{Ni}, \mathrm{Zr}$, and $\mathrm{Hf}$ etc. have been doped to prepare Ir-based alloys for improving their high-temperature mechanical performances and workability. Approaches to improve the high-temperature mechanical performance involve two main strengthening mechanisms: solid-solution hardening, coherent and incoherent precipitate hardenings ${ }^{[4,5]}$. It was found in early studies that the strengthening mechanism of Ir-based alloys containing nominally $0.3 \%$ (mass fraction) $\mathrm{W}, 60 \mu \mathrm{g} / \mathrm{g}$ Th and 50 $\mu \mathrm{g} / \mathrm{g} \mathrm{Al}$ is solid-solution hardening which can improve their hot-workability and welding performance. The Ir-based alloy (DOP-26) developed by Liu et al was used to clad the plutonia fuel pellets in radioisotope thermoelectric generators for space power applications ${ }^{[5-7]}$. However, this Ir-based alloy still fails in a brittle intergranular manner under high-temperature impact conditions. Thus, much researches on doping some microele- ments have been conducted to change iridium alloys' fracture manners, but the effects are not obvious ${ }^{[1,2,5,6]}$. Recently, the binary and ternary alloys such as Ir-Zr, Ir-Nb, Ir-Zr-Hf and Ir-Nb-Ni etc. have been developed, and the results reveal that these Ir-based alloys have excellent high-temperature strength. Of then, Ir-Zr, Ir-Hf and Ir-Zr-Hf binary and ternary alloys have attracted more special attention for their coherent dual-phase fcc $/ L 1_{2}$ structure, which strongly improve the high-temperature strength of these superalloys ${ }^{[8-10]}$.

As a rule, Ir-based alloys are prepared by arc-melting process. Although high density is achieved, the alloys have very large crystal grains due to high temperature and slow cooling rate during melting. The large crystal grains may lead to intercrystalline cracking under deforming, which is one of drawbacks of arc-melting method. Powder metallurgy (P/M) processing is proved to be an effective method to prepare refractory materials (such as W, Mo etc.) with fine crystal grains and homogeneous structure which is beneficial to deformation working. Therefore, an attempt is made to prepare Ir-4Zr- $0.3 \mathrm{~W}$ alloys by $\mathrm{P} / \mathrm{M}$ method and to analyse their microstructures in this paper.

\section{Experimental}

Received date: October 08, 2008; Revised manuscript received date: May 072009

Foundation item: Supported by the National Natural Science Foundation of China (50801053)

Biography: Xiang Changshu, Ph. D., State Key Laboratory of Porous Metal Materials, Northwest Institute for Nonferrous Metal Research, Xi'an 710016, P. R. China, Tel: 0086-29-86231095, E-mail: xiangcs@yahoo.com.cn 
In the present experiment, $\mathrm{P} / \mathrm{M}$ processing was employed to prepare Ir-based alloy containing 4\% $\mathrm{Zr}$ and $0.3 \% \mathrm{~W}$ (at $\%$ ). Firstly, in order to obtain homogenous alloying powder, a small amount of $\mathrm{Ir}-\mathrm{ZrH}_{2}-\mathrm{W}$ powder mixture was prepared by blending Ir (purity 99.99\%, average particle size $37 \mu \mathrm{m}$ ), $\mathrm{ZrH}_{2}$ (purity 99\%, average particle size $1.04 \mu \mathrm{m}$ ) and $\mathrm{W}$ (purity $99.9 \%$, average particle size $3 \mu \mathrm{m}$ ) powders. High-energy ball milling was performed in Certiprep ball mixer (SPEX 8000M) for 2, 4, 8, 12 and $24 \mathrm{~h}$, respectively, using methyl alcohol as a process agent. In addition, the powder ball-milled for $24 \mathrm{~h}$ was calcined at $1300{ }^{\circ} \mathrm{C}$ for $4 \mathrm{~h}$ in vacuum to investigate the phase composition after heat treating. Secondly, $\mathrm{Ir}-\mathrm{ZrH}_{2}-\mathrm{W}$ powder mixture ball-milled for $24 \mathrm{~h}$ was added into a mass of iridium powder to obtain the final composite powder with a composition of $\mathrm{Ir}-4 \mathrm{ZrH}_{2}-0.3 \mathrm{~W}$ (at \%), which was then mixed in a planetary ball mixing attritor for $3 \mathrm{~h}$ using methyl alcohol as agent. After dried at $80{ }^{\circ} \mathrm{C}$ for $24 \mathrm{~h}$, the mixed powder was packed in a plastic mold and compacted by cold isostatic pressing (CIP) at $200 \mathrm{MPa}$ for $60 \mathrm{~s}$. Finally, the as-prepared greens were pre-sintered at $1500{ }^{\circ} \mathrm{C}$ for $4 \mathrm{~h}$ in vacuum, and then sintered at $2190^{\circ} \mathrm{C}$ for $3 \mathrm{~h}$ in hydrogen atmosphere. The powder samples and sintered alloys were characterized by $\mathrm{X}$-ray powder diffraction with $\mathrm{CuK} \alpha$ radiation $(\lambda=15.4056 \mathrm{~nm})$ The density of the alloy was measured by Archimedes' method. The microstructures of the samples were observed by scanning electron microscopy (SEM, JSM-6040, $20 \mathrm{kV}$ ) and filed emission scanning electron microscopy (FESEM, JSM-6700F, 30 $\mathrm{kV}$ ). In addition, Ir-Zr-W alloy with the same composition was prepared by arc-melting method in order to compare the microstructure.

\section{Results and Discussion}

\subsection{Ir-Zr-W alloy powder}

Preparation of homogeneous alloy powder is the key step to fabricate high performance Ir-based alloy. Hence, superfine $\mathrm{ZrH}_{2}$ powder with average particle size $1.04 \mu \mathrm{m}$ and iridium powder with $37 \mu \mathrm{m}$ were chosen as starting materials. In the present experiment, the mixing effect of high-energy ball milling for $24 \mathrm{~h}$ is quite obvious. Fig. 1 shows the FESEM image of pure Ir powder and FESEM backscattered electron image of $\mathrm{Ir}_{-} \mathrm{ZrH}_{2}-\mathrm{W}$ mixture powder after $24 \mathrm{~h}$ high-energy ball milling. From Fig.1a, it is clear to see that pure iridium powder usually takes on the agglomerates consisting of very fine particles. But after long-time ball milling, the iridium particles were ground and crashed to deform, which can be seen from Fig.1b. In Fig.1b, the white grains are iridium particles and the grey grains are $\mathrm{ZrH}_{2}$ particles. It is obvious that Ir- $\mathrm{ZrH}_{2}-\mathrm{W}$ mixture is very homogeneous and some superfine $\mathrm{ZrH}_{2}$ granules are embedded in the relative large iridium grains after powerful long-time ball-milling.

However, there was no $\mathrm{Ir}_{3} \mathrm{Zr}$ phase formation in $\mathrm{Ir}-\mathrm{ZrH}_{2}-\mathrm{W}$ mixture even milled for $24 \mathrm{~h}$. The XRD pattern of $\mathrm{Ir}-\mathrm{ZrH}_{2}-\mathrm{W}$ mixture is shown in Fig. 2a. From the pattern, only Ir and

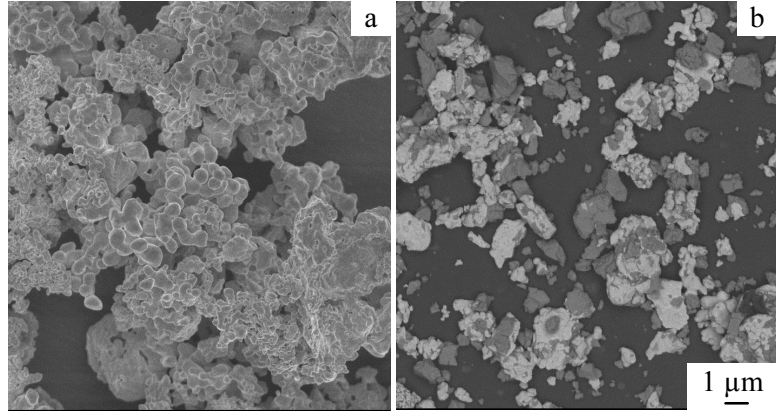

Fig.1 FESEM image of pure Ir powder (a) and FESEM backscattered electron image of $\mathrm{Ir}-\mathrm{ZrH}_{2}-\mathrm{W}$ mixture powder after $24 \mathrm{~h}$ high-energy ball milling (b)

$\mathrm{ZrH}_{2}$ diffraction peaks were detected, and no $\mathrm{Ir}_{3} \mathrm{Zr}$ phase diffraction peak was found within the sensitivity of XRD, indicating that $\mathrm{Ir}_{3} \mathrm{Zr}$ phase could not form and no mechanical alloying phenomenon occurred during $24 \mathrm{~h}$ ball-milling. From the experimental results, we can know that the mechanical alloying time for high-energy ball-milling need more time because iridium powder not only is very stiff, but also has a relatively high inertia, so it is not easy to react with $\mathrm{ZrH}_{2}$ powders even the particle size of $\mathrm{ZrH}_{2}$ powder used in this experiment is superfine. But Ir in the mixture was completely transmitted to $\mathrm{Ir}_{3} \mathrm{Zr}$ phase by calcinating at $1300{ }^{\circ} \mathrm{C}$ for $4 \mathrm{~h}$ under vacuum conditions. Fig. $2 \mathrm{~b}$ shows the XRD pattern of the powder mixture calcinated at $1300{ }^{\circ} \mathrm{C}$ for $4 \mathrm{~h}$. As seen from it, only $\mathrm{Ir}_{3} \mathrm{Zr}$ diffraction peaks were detected, which shows the reaction between iridium and $\mathrm{ZrH}_{2}$ powders occurred during calcining. Though the melting point of $\operatorname{Ir}_{3} \mathrm{Zr}$ is as high as $2280{ }^{\circ} \mathrm{C}$, the calcinating temperature of $\mathrm{Ir}_{3} \mathrm{Zr}$ in the present experiment was only $1300{ }^{\circ} \mathrm{C}$. At such lower temperature the formation of $\operatorname{Ir}_{3} \mathrm{Zr}$ is dominantly attributed to the dehydrogenation of superfine $\mathrm{ZrH}_{2}$ powder and the solid phase diffusion reaction among the active $\mathrm{Zr}$ particles and $\mathrm{Ir}$ particles. As we know, $\mathrm{ZrH}_{2}$ powder begins to dehydrogen at $300{ }^{\circ} \mathrm{C}$ and hydrogenation automatically deviate rapidly from $\mathrm{ZrH}_{2}$ at $600{ }^{\circ} \mathrm{C}$. When hydrogen leaves, new $\mathrm{Zr}$ particles with active and large specific surface will appear around the iridium particles. So it is easy to react between iridium and $\mathrm{Zr}$, and finally $\mathrm{Ir}_{3} \mathrm{Zr}$ phase would be formed. The phenomenon also occurred in Ir-4Zr-0.3W mixing powder. As shown in Fig. $2 \mathrm{c}$, the final phase compositions include essential component iridium and a small amount of $\mathrm{Ir}_{3} \mathrm{Zr}$, and almost no $\mathrm{ZrH}_{2}$ phase exists in the mixture powder after calcination.

\subsection{Microstructure of Ir-Zr-W alloy after pre-sintering and sintering}

In this investigation, two-step sintering was performed to improve the density of Ir-based alloys. Upon pre-sintering in vacuum at low temperature and sintering in hydrogen at high temperature, $\mathrm{ZrH}_{2}$ reacted with iridium completely, and no $\mathrm{ZrH}_{2}$ existed in the finally alloy according to XRD pattern of the Ir-based alloy, shown in Fig. 3. Because of the small con- 
tent of $\mathrm{W}$, no characteristic peaks of $\mathrm{W}$ were detected in the alloy. But SEM EDS analysis result shows that there is approximate 0.228 at $\%$ tungsten in the alloy, which can be seen from Fig.4. Fig.5a shows the typical image of the fracture surface of the alloy sintered at $1500{ }^{\circ} \mathrm{C}$. During the pre-sintering, $\mathrm{Ir}_{3} \mathrm{Zr}$ phase was formed when $\mathrm{ZrH}_{2}$ was decomposed to $\mathrm{Zr}$ and hydrogen. It can be seen from the Fig. 5a that the sintering necks of $\mathrm{Ir} / \mathrm{Ir}, \mathrm{Ir} / \mathrm{Ir}_{3} \mathrm{Zr}$ particles appeared and grew below $1500{ }^{\circ} \mathrm{C}$. The relative density reached $85 \%$ and there still were a few pores. After sintering at $1500{ }^{\circ} \mathrm{C}$ for $4 \mathrm{~h}$, the average grain size increased to $3 \mu \mathrm{m}$. Fig. $5 \mathrm{~b}$ shows the morphology of the cross-section of Ir-based alloy sintered at $2190{ }^{\circ} \mathrm{C}$. When the sintering temperature was elevated to $2190{ }^{\circ} \mathrm{C}$, the grains grew obviously and their average grain sizes increase to 4-5 $\mu \mathrm{m}$. The gas pores decreased obviously with the growth of the crystal grain and the relative density increased to $95 \%$. In spite of that the density of Ir-Zr-W alloy by P/M processing is relatively lower than that of Ir-Zr-W alloy by arc-melting, the grain size of Ir-Zr-W alloy prepared by $\mathrm{P} / \mathrm{M}$ method is only $1 / 10$ of that by arc-melting, shown in Fig.5b and c, and it shows the advantage of $\mathrm{P} / \mathrm{M}$ processing. From Fig. $5 \mathrm{~b}$, it can be further seen that no obvious cracking occurred in the cross-section of the alloy by $\mathrm{P} / \mathrm{M}$ processing when the alloy was fractured by

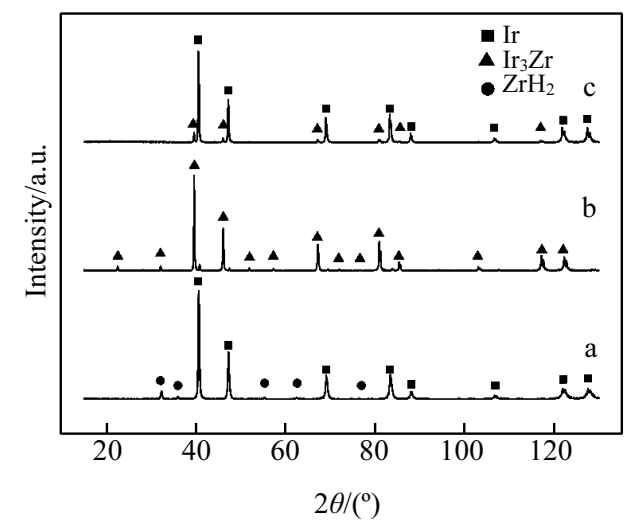

Fig.2 XRD patterns of $\mathrm{Ir}_{-}-\mathrm{ZrH}_{2}-\mathrm{W}$ powder ball-milled for $24 \mathrm{~h}$ (a), Ir- $\mathrm{ZrH}_{2}-\mathrm{W}$ powder ball-milled for $24 \mathrm{~h}$ and calcined in vacuum for $4 \mathrm{~h}$ (b), and $\mathrm{Ir}-4 \mathrm{ZrH}_{2}-0.3 \mathrm{~W}$ powder calcined in vacuum for $4 \mathrm{~h}(\mathrm{c})$ hammering, while there was obvious intergranular cracking in the cross-section of the alloy by arc-melting process under the same failure condition.

According to the Ir-Zr binary phase diagram, the addition of more than 3 at $\% \mathrm{Zr}$ will lead to forming of an $\operatorname{Ir}_{3} \mathrm{Zr}$ intermetallic phase for the low solubility of $\mathrm{Zr}$ in $\mathrm{Ir}$, which is consistent with our X-ray diffraction results shown in Fig. $3^{[5]}$. Fig. 6 shows the backscattered electron image of $\mathrm{Ir}-\mathrm{Zr}-\mathrm{W}$ alloy sintered at $2190{ }^{\circ} \mathrm{C}$. From the figure, it can be seen that $\mathrm{Ir}_{3} \mathrm{Zr}$ particles, the relative black granules, are homogeneously embedded in the matrix of $\mathrm{Ir}$, which means that $\mathrm{Ir}_{3} \mathrm{Zr}$ phase can be generated in-situ in the alloy.

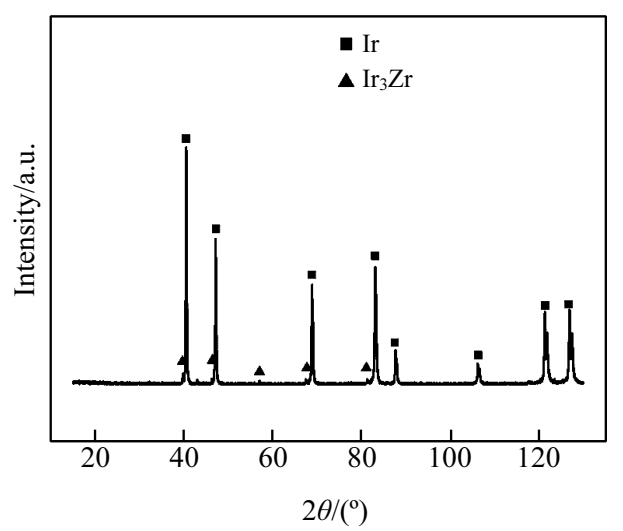

Fig.3 XRD pattern of Ir-based alloy sintered at $2190{ }^{\circ} \mathrm{C}$ for $3 \mathrm{~h}$

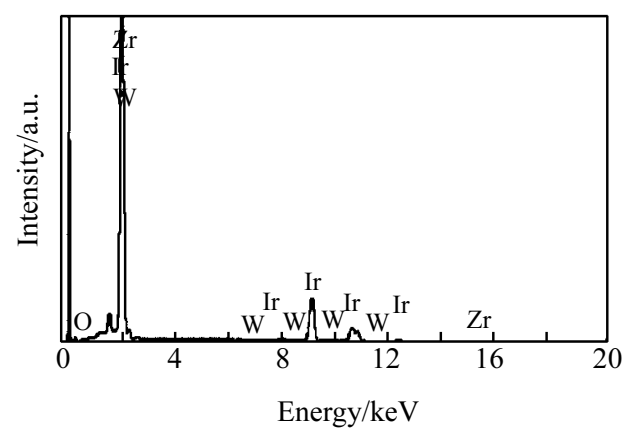

Fig.4 SEM EDS of Ir-Zr-W alloy sintered at $2190^{\circ} \mathrm{C}$ for $3 \mathrm{~h}$
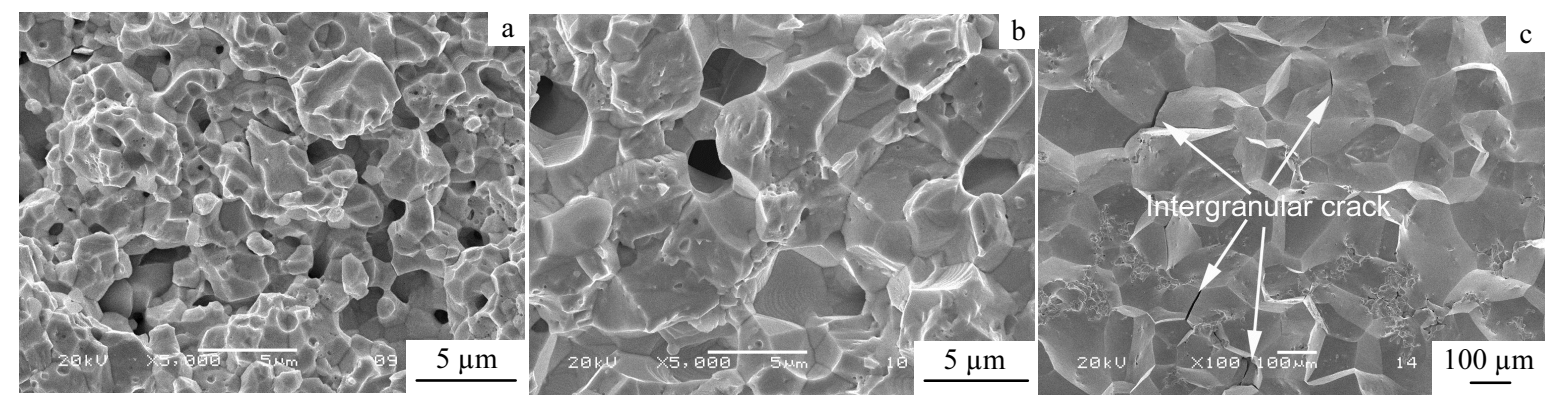

Fig.5 Fractographs of Ir-Zr-W alloys: (a) pre-sintered at $1500{ }^{\circ} \mathrm{C}$, (b) sintered at $2190{ }^{\circ} \mathrm{C}$ and (c) prepared by arc-melting method 


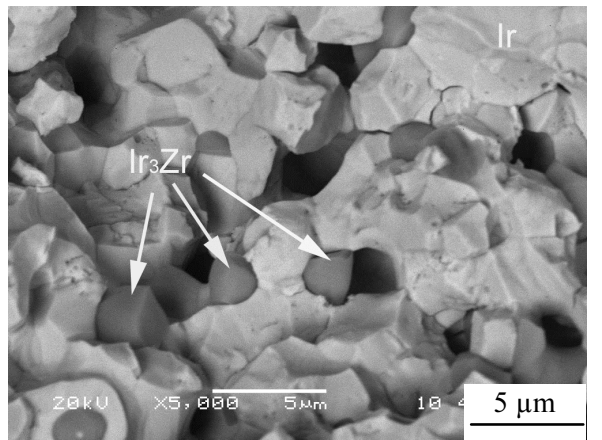

Fig.6 SEM backscattered electron image of Ir-Zr-W alloy sintered at $2190{ }^{\circ} \mathrm{C}$

\section{Conclusions}

1) $\mathrm{Ir}-4 \mathrm{Zr}-0.3 \mathrm{~W}$ (at $\%$ ) alloys can be fabricated by $\mathrm{P} / \mathrm{M}$ processing.

2) As-prepared $\mathrm{Ir}-\mathrm{ZrH}_{2}-\mathrm{W}$ mixture has high reactivity after $24 \mathrm{~h}$ ball milling, and $\mathrm{Ir}^{-} \mathrm{ZrH}_{2}$ in the mixture will be completely transmitted into $\mathrm{Ir}_{3} \mathrm{Zr}$ phase during calcinating below $1300{ }^{\circ} \mathrm{C}$ in vacuum.

3) The relative density of Ir-based alloys can reach $85 \%$ after pre-sintering at $1500{ }^{\circ} \mathrm{C}$ and finally $95 \%$ after sintering at $2190{ }^{\circ} \mathrm{C}$.
4) The average grain size of Ir-based alloy prepared by $\mathrm{P} / \mathrm{M}$ method is within $4-5 \mu \mathrm{m}$, and $\mathrm{Ir}_{3} \mathrm{Zr}$ phase can be generated in-situ in the alloy.

\section{References}

1 Mckamey C G, George E P, Lee E H et al. Scripta Materials[J], 2000, 42: 9

2 George E P, Mckamey C G, Ohriner E K et al. Materials Science and Engineering[J], 2001, A 319 321: 466

3 Cawkwell M J, Nguyen-Manh D, Woodward C et al. Science [J], 2005, 309: 1059

4 Sha J B, Yamabe-Mitarai Y. Scripta Materials [J], 2006, 54: 115

5 Liu Y, Liu C T, Heatherly L et al. Journal of Alloys and Compounds[J], 2008, 459 (1 2): 130

6 Gubbi A N, George E P, Ohriner E K et al. Acta Materials[J], 1998, 46 (3): 893

7 Mckamey C G, Lee E H, Cohron J W et al. Scripta Materials[J], 1996, 35 (2): 181

8 Yamabe-Mitarai Y, Ro Y, Maruko T et al. Metallurgica and Materials Transactions A [J], 1998, 29A: 537

9 Sha J B, Yamabe-Mitarai Y, Harada $\mathrm{H}$ et al. Intermetallics $[\mathrm{J}]$, 2006, 14: 1364

10 Liu C T, George E P, Bloom E E et al. U S Patent: $6982122-$ $\mathrm{B} 2[\mathrm{P}], 2005$

\title{
粉末冶金工艺制备 Ir-Zr-W 合金及其显微结构研究
}

\author{
向长淑, 葛 渊, 刘海彦, 黄愿平, 汤慧萍 \\ (西北有色金属研究院 金属多孔材料国家重点实验室，陕西 西安 710016)
}

\begin{abstract}
摘 要: 采用粉末冶金工艺制备 Ir- $4 \mathrm{Zr}-0.3 \mathrm{~W}$ (at \%)合金, 并对合金粉末和合金的相组成和显微结构分别进行了研究。发现, 即使对合金 粉末高能球磨 $24 \mathrm{~h}$, 也无法生成 $\operatorname{Ir}_{3} \mathrm{Zr}$ 相, 不发生机械合金化现象。但是, 当合金粉末经 $1300{ }^{\circ} \mathrm{C}$ 煅烧后, 完全转变为 $\operatorname{Ir}_{3} \mathrm{Zr}$ 相。采用粉 末冶金工艺制备的铱合金晶粒尺寸细小，约 4 5 $5 \mathrm{~m}$, 并且在铱合金中原位生成 $\operatorname{Ir}_{3} \mathrm{Zr}$ 相颗粒。
\end{abstract}

关键词: 铱; 微结构; 烧结; 粉末冶金

作者简介: 向长淑, 男, 1979 年生, 博士, 西北有色金属研究院 金属多孔材料国家重点实验室, 陕西 西安 710016, 电话: 029-86231095, Email: xiangcs@yahoo.com.cn 